\title{
Ultrasound enhanced prehospital thrombolysis using microbubbles infusion in patients with acute ST elevation myocardial infarction: Rationale and design of the Sonolysis study
}

\author{
Jeroen Slikkerveer*1,5, Pieter A Dijkmans ${ }^{1}$, Gertjan T Sieswerda², \\ Pieter AFM Doevendans ${ }^{2}$, Arie PJ van Dijk ${ }^{3}$, Freek WA Verheugt ${ }^{3}$, \\ Thomas R Porter ${ }^{4}$ and Otto Kamp ${ }^{1,5}$
}

\begin{abstract}
Address: ${ }^{1}$ Department of Cardiology and Institute of Cardiovascular Research, VU University Medical Center, Amsterdam, The Netherlands ${ }^{2}$ University Medical Center Utrecht, Utrecht, The Netherlands, ${ }^{3}$ Radboud University Nijmegen Medical Center, Nijmegen, The Netherlands, ${ }^{4}$ University of Nebraska Medical Center, Omaha, Nebraska, USA and ${ }^{5}$ Interuniversity Cardiology Institute of the Netherlands, Utrecht, The Netherlands

Email: Jeroen Slikkerveer* - j.slikkerveer@vumc.nl; Pieter A Dijkmans - pa.dijkmans@vumc.nl;

Gertjan T Sieswerda - G.T.Sieswerda@umcutrecht.nl; Pieter AFM Doevendans - P.Doevendans@umcutrecht.nl; Arie PJ van

Dijk - A.vanDijk@cardio.umcn.nl; Freek WA Verheugt - F.Verheugt@cardio.umcn.nl; Thomas R Porter - trporter@unmc.edu;

Otto Kamp - o.kamp@vumc.nl

* Corresponding author
\end{abstract}

Published: 10 December 2008

Trials 2008, 9:72 doi:10.1186/1745-62/5-9-72

This article is available from: http://www.trialsjournal.com/content/9/I/72

(c) 2008 Slikkerveer et al; licensee BioMed Central Ltd.

This is an Open Access article distributed under the terms of the Creative Commons Attribution License (http://creativecommons.org/licenses/by/2.0), which permits unrestricted use, distribution, and reproduction in any medium, provided the original work is properly cited.

\begin{abstract}
Background -: Experimental studies have shown that ultrasound contrast agents enhance the effectiveness of thrombolytic agents in the presence of ultrasound in vitro and in vivo. Recently, we have launched a clinical pilot study, called "Sonolysis", to study this effect in patients with ST-elevation myocardial infarction based on proximal lesions of the infarct-related artery.

Methods/design -: In our multicenter, randomized, placebo controlled clinical trial we will include patients between 18 and 80 years of age with their first ST-elevation myocardial infarction based on a proximal lesion of the infarct-related artery. After receiving a single bolus alteplase $50 \mathrm{mg}$ IV (Actilyse ${ }^{\circledR}$ Boehringer Ingelheim $\mathrm{GmbH}$ ), a loading dose of aspirin $500 \mathrm{mg}$, and heparin $5000 \mathrm{IU}$ in the ambulance according to the prehospital thrombolysis protocol, patients, following oral informed consent, are randomized to undergo 15 minutes of pulsatile ultrasound with intravenous administration of ultrasound contrast agent or placebo without ultrasound. Afterwards coronary angiography and, if indicated, percutaneous coronary intervention will take place. A total of 60 patients will be enrolled in approximately I year.

The primary endpoints are based on the coronary angiogram and consist of TIMI flow, corrected TIMI frame count, and myocardial blush grade. Follow-up includes 12-lead ECG, 2D-echocardiography, cardiac MRI, and enzyme markers to obtain our secondary endpoints, including the infarct size, wall motion abnormalities, and the global left ventricular function.

Discussion -: The Sonolysis study is the first multicenter, randomized, placebo controlled clinical trial investigating the therapeutic application of ultrasound and microbubbles in acute ST-elevation myocardial infarction patients. A positive finding may stimulate further research and technical innovations to implement the treatment in the ambulance and maybe obtain even more patency at an earlier stage.
\end{abstract}

Trial registration -: Trialregister NTR I6I 


\section{Background}

Thrombo-occlusive cardiovascular disease is the leading cause of mortality in the western world. Among these, acute ST-elevation myocardial infarction (STEMI) is an important disease with high morbidity and mortality. In the course of years, two major treatment strategies have been developed, aiming at immediate restoration of coronary blood flow.

Currently, the first choice of treatment in patients with acute STEMI is primary percutaneous coronary intervention (PCI). However, its feasibility depends on the availability of equipment and trained personnel. As a result, thrombolysis is worldwide the most commonly used therapy for patients with STEMI[1]. Nevertheless, thrombolysis is known to have a relatively low recanalization rate and is related to more haemorrhagic complications[2].

Hence, there is an ongoing search for a non-invasive and easy applicable therapeutic strategy with less serious sideeffects, still based on the early restoration of coronary blood flow.

One of the new non-invasive therapy strategies is the use of ultrasound and an ultrasound contrast agent, in combination with thrombolysis[3,4].

Previous studies have indicated that ultrasound alone may accelerate fibrinolysis[5]. The addition of microbubbles being destroyed by high pressure ultrasound leads to an even greater increase of fibrinolysis. There are three proposed mechanisms which lead to this increase. The first is the occurrence of shear stress based on micro-jets which are created after the destruction of the microbubbles by ultrasound[6]. The second mechanism is the generation of reactive oxygen species in endothelial cells[7]. The third proposed mechanism for the increase of fibrinolysis is temperature rise which also takes place after the microbubbles collapse under influence of ultrasound[8]. Although the full mechanism remains to be resolved, the application of ultrasound alone and ultrasound in combination with contrast agents have proven their value by enhancing clot dissolution, by creating microholes in fresh thrombi. Tachibana and Tachibana were among the first to describe the effect of an ultrasound contrast agent on fibrinolysis in vitro[9]. They added urokinase with microbubbles (Albunex) and ultrasound, which led to a significant increase in fibrinolysis. This result was confirmed by other in vitro studies in the course of years [1013] (Table 1).

Birnbaum et al. were among the first to conduct an in vivo study[14]. They used rabbit iliofemoral arteries to examine the effect of ultrasound and microbubbles on fibrinolysis, without using any fibrinolytics. The recanalization rate in the artery treated with a combination of microbubbles and ultrasound was significantly higher compared to the application of ultrasound or microbubbles alone.

Siegel et al. conducted an other in vivo study in rabbit iliofemoral arteries[15]. They showed a significant increase of fibrinolysis in the combination of streptokinase and ultrasound compared to streptokinase alone. Adding microbubbles did not made any difference, however the combination of the three was still better then streptokinase alone.

Other in vivo studies confirmed a higher recanalization rate using ultrasound and microbubbles[16,17] (Table 1).

In 2004, the CLOTBUST investigators published results of a multicenter phase II trial conducted in patients with acute stroke[18]. They randomly assigned 126 patients to receive continuous ultrasound or placebo following treatment with intravenous t-PA $(0.9 \mathrm{mg} / \mathrm{kg}$ with a maximum of $90 \mathrm{mg}$ ) within 3 hours after the onset of symptoms. The results within 2 hours after administration showed a significant increase of complete recanalization in the ultrasound group compared to placebo. It also showed a nonsignificant trend towards recovery from stroke, compared with placebo.

Molina et al. conducted a trial in which they added microbubbles on top of ultrasound and t-PA[19]. The addition of microbubbles induced further enhancement of ultrasound augmented thrombolysis, leading to more complete recanalization.

The first to conduct a study in which ultrasound and thrombolytic therapy was combined in a small group of STEMI patients were Cohen et al. They found no major adverse events and regarding efficacy their outcome compared favourably with historical data[20].

However, until now the combination of ultrasound, ultrasound contrast agents (UCA), and thrombolytic therapy has never been tested in STEMI patients. Therefore, we will perform the first study in a pilot design in patients with STEMI, in which we compare the combination of ultrasound and microbubbles with placebo after prehospital thrombolysis.

\section{Methods and design \\ Study design}

Sonolysis is designed as a multicenter, randomized, placebo controlled clinical trial that will be conducted in the VU University Medical Center Amsterdam, University Medical Center Utrecht, and Radboud University Nijmegen Medical Center. 
Table I: Studies assessing the influence of microbubbles and ultrasound on thrombolysis

\begin{tabular}{|c|c|c|c|c|c|}
\hline Author(s)/reference & Microbubble & Target in vivo/in vitro & TL, US, MB & US frequency & Outcome \\
\hline $\begin{array}{l}\text { Tachibana and } \\
\text { Tachibana[9] }\end{array}$ & Albumin MB (albunex) & In vitro thrombus & UK, US and MB & $170 \mathrm{kHz}, 0.5 \mathrm{~W} / \mathrm{cm}^{2}$ & $\begin{array}{l}\text { Significantly increased } \\
\text { thrombolysis with } \\
\text { thrombolytics, US and MB }\end{array}$ \\
\hline Kondo et al. [10] & $\begin{array}{l}\text { Air-filled MB with } \\
\text { galactose/palmitic acid } \\
\text { shell }\end{array}$ & $\begin{array}{l}\text { In vitro white } \\
\text { thrombus }\end{array}$ & t-PA, US and MB & $\begin{array}{l}10 \mathrm{MHz}, 0.5-1.0 \mathrm{~W} / \\
\mathrm{cm}^{2}\end{array}$ & $\begin{array}{l}\text { Significant enhancement of } \\
\text { thrombus reduction by MB }\end{array}$ \\
\hline Nishioka et al. [I I] & DDFP & $\begin{array}{l}\text { In vitro and in vivo } \\
\text { canine iliofemoral } \\
\text { arteries }\end{array}$ & $M B$ and US & $20 \mathrm{kHz}, 1.5 \mathrm{~W} / \mathrm{cm}^{2}$ & $\begin{array}{l}\text { Increased clot disruption } \\
\text { and recanalization with US } \\
\text { and MB }\end{array}$ \\
\hline Porter et al. [12] & Air-filled MB/PESDA MB & In vitro thrombus & UK, US and MB & $20 \mathrm{kHz}, 40 \mathrm{~W} / \mathrm{cm}^{2}$ & $\begin{array}{l}\text { Significant better } \\
\text { thrombolysis of PESDA than } \\
\text { air-MB. Optimal } \\
\text { thrombolysis with UK and } \\
\text { MB }\end{array}$ \\
\hline Mizushige et al. [13] & $\begin{array}{l}\text { Albumin Shell, air-filled/ } \\
\text { galactose shell air-filled/ } \\
\text { DDFP-filled MB }\end{array}$ & In vitro thrombus & t-PA, US, MB & $10 \mathrm{MHz}, 1.02 \mathrm{~W} / \mathrm{cm}^{2}$ & $\begin{array}{l}\text { Thrombolysis was greatest } \\
\text { in DDFP-MB-group }\end{array}$ \\
\hline Birnbaum et al. [14] & PESDA MB & $\begin{array}{l}\text { In vivo canine } \\
\text { iliofemoral artery }\end{array}$ & US and $M B$ & Up to $160 \mathrm{~W} / \mathrm{cm}^{2}$ & $\begin{array}{l}\text { Significant higher } \\
\text { recanalization rate with MB }\end{array}$ \\
\hline Siegel et al. [15] & DDFP/PESDA & $\begin{array}{l}\text { In vivo rabit iliofemoral } \\
\text { artery and canine LAD }\end{array}$ & SK, US, MB & $\begin{array}{l}20-37 \mathrm{kHz}, 1.5-160 \\
\mathrm{~W} / \mathrm{cm}^{2}\end{array}$ & $\begin{array}{l}\text { Increased clot dissolution } \\
\text { with US, MB and SK }\end{array}$ \\
\hline Culp et al. [16] & $\begin{array}{l}\text { PESDA tagged with } \\
\text { eptifibatide }\end{array}$ & $\begin{array}{l}\text { In vivo pigs ascending } \\
\text { pharyngeal artery }\end{array}$ & US and MB & $\mathrm{I} \mathrm{MH}, 2 \mathrm{~W} / \mathrm{cm}^{2}$ & $\begin{array}{l}\text { Improvement of } \\
\text { recanalization rate in } \\
\text { eptifibatide tagged PESDA }\end{array}$ \\
\hline Xie et al. [I7] & Definity & $\begin{array}{l}\text { In vivo canine femoral } \\
\text { artery and vein }\end{array}$ & US and MB & $\begin{array}{l}\text { I MHz, } 0.4-0.6 \mathrm{~W} / \\
\mathrm{cm}^{2} \text { and } 10 \mathrm{~W} / \mathrm{cm}^{2}\end{array}$ & $\begin{array}{l}\text { Higher recanalization rates } \\
\text { with } M B \text { and US compared } \\
\text { to US alone }\end{array}$ \\
\hline $\begin{array}{l}\text { CLOTBUST } \\
\text { investigators[18] }\end{array}$ & - & $\begin{array}{l}\text { In vivo middle cerebral } \\
\text { artery Phase } 2 \text { trial }\end{array}$ & t-PA and US & $2 \mathrm{MHz}$ & $\begin{array}{l}\text { Ultrasound augments t-PA } \\
\text { induced arterial } \\
\text { recanalization }\end{array}$ \\
\hline Molina et al. [19] & Galactose MB (Levovist) & $\begin{array}{l}\text { In vivo middle cerebral } \\
\text { artery phase } 2 \text { trial }\end{array}$ & t-PA, US, MB & $2 \mathrm{MHz}$ & $\begin{array}{l}\text { MB safely induces } \\
\text { acceleration of US enhanced } \\
\text { thrombolysis }\end{array}$ \\
\hline Cohen et al. [20] & - & $\begin{array}{l}\text { In vivo STEMI phase } 2 \\
\text { trial }\end{array}$ & rt-PA and US & $27 \mathrm{kHz}$ & No major adverse events \\
\hline
\end{tabular}

$\mathrm{MB}=$ microbubble; $\mathrm{US}=$ ultrasound; $\mathrm{TL}=$ thrombolytic; $(\mathrm{r}) \mathrm{t}-\mathrm{PA}=$ (recombinant) tissue plasminogen activator; PESDA = perfluorocarbon-exposed sonicated dextrose albumin; UK = urokinase; DDFP = dodecafluoropentane; LAD = left artery descending; $S K=$ streptokinase

We will include patients between 18 and 80 years of age with an acute STEMI based on a proximal lesion. To make sure that we deal with a blocked proximal major epicardial coronary artery our inclusion criteria consist of a sum of ST-elevation of $6 \mathrm{~mm}$ or more in combined leads and $1 \mathrm{~mm}$ or more ST-elevation in lead V3R when there is an inferior infarct. The exclusion criteria are mentioned in Table 2.

Patients are randomized in either a placebo group or a group that receives the ultrasound contrast agent Luminity ${ }^{\circledR}$.

Table 2: Exclusion criteria of the Sonolysis study

- Clinical instability

- Previous Q-wave myocardial infarction

- Contra indications alteplase (Table 3)

- Known pulmonary hypertension $(>90 \mathrm{mmHg})$

- Known allergy of Luminity ${ }^{\circledR}$
Randomization will take place on announcement by the ambulance of a patient with an eligible STEMI. This announcement is done through the unique Lifenet system. An ECG of a patient with chest pain is recorded by ambulance personnel and sent to a computer in the coronary care unit of the hospital. There, the cardiology resident on call consults the intervention cardiologist and together they will check the ECG for the inclusion criteria. If the patient is eligible for the study, the ambulance personnel will be informed. This all is summarised in a flow chart (Figure 1)

Randomization will be done by opening a sealed envelope containing the contrast agent Luminity ${ }^{\circledast}$ or saline $0.9 \%$, the placebo.

Patients will be pre-treated in the ambulance with a loading dose of aspirin $500 \mathrm{mg}$ iv., heparin $5000 \mathrm{IU}$ iv., and a 


\section{Eligible acute infarct patients}

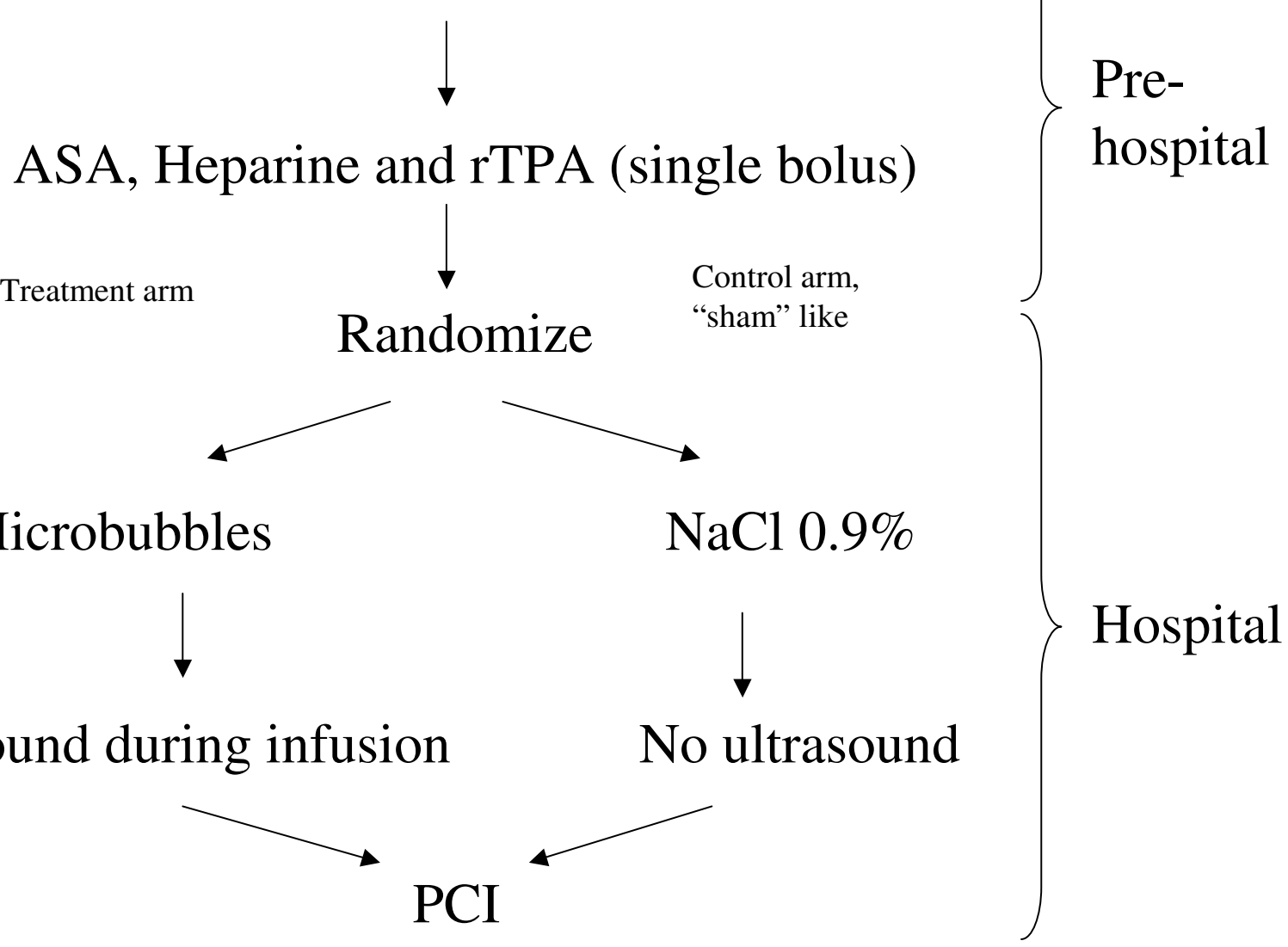

\section{Figure I}

Flow chart of the study design, divided in a hospital and a pre- hospital part.

single bolus alteplase $50 \mathrm{mg}$ IV (Actilyse ${ }^{\circledR}$ Boehringer Ingelheim $\mathrm{GmbH}$ ). The latter will be administered in approximately 3 minutes if there are no contra-indications (Table 3). This is in accordance with the prehospital thrombolysis protocol[21,22].
To avoid any time delay, informed consent will be obtained orally, prior to PCI at arrival in the hospital. Written informed consent will be given after primary PCI when the patient is in a stable clinical condition.

Table 3: Contraindications alteplase.

- Reduced consciousness

- Paralysis

- Arterial hypertension (systolic pressure > $180 \mathrm{mmHg}$ )

- Known or suspected haemorrhagic diathesis

- Possible pregnancy

- Any history of stroke

- In the past 3 months $\& \# \times 2218 ;$ Significant trauma $\& \# \times 2218$; Major surgery $\& \# \times 2218 ;$ Haemoptysis

$\& \# \times 2218$; Documented ulcerative gastrointestinal disease $\& \# \times 2218$; Manifest or recent severe or dangerous bleeding

- Allergy to streptokinase or t-PA

- Systolic blood pressure of less than $80 \mathrm{mmHg}$ during more than 5 minutes with clinical symptoms of shock 
At arrival in the hospital, patients receive, after oral informed consent, either placebo (i.e. $50 \mathrm{ml}$ saline $0.9 \%$ ) without ultrasound, or the ultrasound contrast agent Luminity ${ }^{\circledast}$ during simultaneously pulsatile ultrasound application.

We will use one flacon Luminity ${ }^{\oplus}$ of $1.5 \mathrm{ml}$ which contains 225 microliter perflutren, a high-molecular-weight gas, which increases the stability of the microbubbles. This will be shaken in the Vialmix ${ }^{\mathrm{TM}}$ for 45 seconds, to produce the microspheres. After that $48.5 \mathrm{ml}$ of saline $0.9 \%$ will be added to create a $50 \mathrm{ml}$ milky white suspension. The suspension or placebo will be administered intravenously in 15 minutes with an infusion rate of $200 \mathrm{ml} / \mathrm{h}$.

Luminity ${ }^{\otimes}$ is registered in the Netherlands as a diagnostic contrast agent to improve imaging quality during echocardiography. Most occurring complications are minor, like headache (2.0\%), flushing (1.0\%), and back pain (0.9\%). Allergic reactions happen approximately in one of every 10.000 patients[23].

The dose of $1.5 \mathrm{ml}$ Luminity ${ }^{\circledR}$ has been shown to be safe and well tolerated. Thus, we expect no difference in adverse events between both groups.

\section{Endpoints}

The primary endpoints of the study are TIMI flow grade, corrected TIMI frame count, and myocardial blush grade, to document the patency of the culprit vessel. All of these are measured during coronary angiography pre-PCI.

Secondary endpoints are ST resolution based on a 12-lead ECG registration during ultrasound, PCI and post-PCI, infarct size derived from measurement of the marker enzymes, and wall motion abnormalities (WMA) measured with 2D-echo and contrast enhanced MRI.

\section{Cardiac imaging}

The ultrasound equipment used in this protocol is the Ie33 (Philips, Eindhoven, the Netherlands). In combination with a X3-1 probe we make 3D full volume images of the aortic root in the parasternal short axis view to ensure that the proximal parts of the epicardial coronary artery system is encompassed within the target zone.

The mechanical index will be set on 1.18 in order to make the microbubble collapse. The frequency we will use is 1.6 $\mathrm{MHz}$ intermittently (5 seconds on, 5 seconds off) to ensure the microbubbles to enter the proximal portion of the occluded coronary artery between the pulses.

During follow-up, a 2D echo will be performed to obtain information about wall motion abnormalities, left ventricle volumes, and ejection fraction.
The standard emergency coronary angiogram will be performed to assess the patency of the culprit lesion, the TIMI flow, the corrected TIMI frame count, and the myocardial blush grade. To obtain the myocardial blush grade the angiographic runs will be prolonged until the venous phase of the contrast passage is seen[24]. The frame rate will be set on 12,5 frames/sec. To calculate the corrected TIMI frame count the score will be adjusted for the used frame rate[25]. If necessary, a PCI will be carried out.

Patients are studied on a clinical 1.5 Tesla MRI scanner within 2 to 9 days after primary PCI, and for 4-month follow-up. ECG-gated cine SSFP (Steady State Free Precession) MR images are obtained during repeated breathholds in the three standard long axis views (four-, threeand two-chamber view). Additional short axis slices are acquired covering the entire left ventricle, to examine regional and global left ventricular function.

After that i.v. injection of Gd-DTPA first-pass perfusion imaging is performed with a saturation-recovery gradientecho pulse sequence. Delayed contrast-enhanced images are acquired 10 minutes post-contrast with an inversionrecovery gradient-echo pulse sequence to identify the location and extent of myocardial infarction. The data are obtained with slice locations identical to the functional images.

\section{Follow-up}

Follow-up examination will exist from 12-lead ECG registration, 2D-echocardiography, contrast enhanced MRI, and biomarkers of myocardial infarction (CK-MB). All serving to achieve the secondary endpoints of this study.

MRI and 2D-echocardiography will be used to assess the global and regional wall motion, left ventricular function, and left ventricular ejection fraction. 12-lead ECG registration will be used to observe the ST-segment resolution and markers to compare infarct size of both groups.

\section{Statistical analysis}

The aim of this pilot study is to investigate whether the combination of ultrasound and microbubbles enhance clot dissolution after pre-treatment of STEMI patients with a loading dose of aspirin $500 \mathrm{mg}$, heparin $5000 \mathrm{IU}$, and alteplase single bolus $50 \mathrm{mg}$.

The reason we use a single bolus alteplase is to avoid serious adverse events. The PACT-trial[26] showed there was no difference in severe complications between the placebo group and the single bolus alteplase group after pretreatment with aspirin and heparin, but there still was a significant increase in TIMI 3 flow in the alteplase group (33\%) compared to placebo (15\%). With our study we are aiming for $65 \%$ TIMI 3 flow in the group treated with 
microbubbles. In order to demonstrate this with a power of $80 \%$ and an $\alpha$ of 0.05 (two sided) we need a sample size of 29 patients per group. Therefore, we are intending to randomize 60 patients in this pilot study.

Obtained baseline data will be presented as mean \pm standard deviation (SD). Differences between the treatment group, with ultrasound and microbubbles, and the control group in baseline data, biomarkers, 2D-echo, and MRI variables will be assessed by unpaired students t-test.

Chi-square analyses will be conducted to observe differences in primary and secondary endpoints between the treatment group and the control group.

All analysis will be performed based on an intention-totreat principle.

\section{List of abbreviations}

PCI: percutaneous coronary intervention; SD: standard deviation; SSFP: Steady State Free Precession; STEMI: STelevation myocardial infarction; UCA: ultrasound contrast agents; WMA: wall motion abnormalities.

\section{Competing interests}

The authors declare that they have no competing interests.

\section{Authors' contributions}

JS in collaboration with PAD and OK designed the study and drafted the manuscript. GTS, PAFMD, AvD, FWAV and TRP revised the manuscript critically. All have given their final approval of the version to be published.

\section{Acknowledgements}

We would like to acknowledge the Royal Netherlands Academy of Arts and Sciences, Amsterdam, the Netherlands for providing the funding for this $04902 \mathrm{ICIN}$-trial. Furthermore we like to thank the echo- and MRItechnicians for making the images during the follow-up.

\section{References}

I. Werf F Van de, Ardissino D, Betriu A, Cokkinos DV, Falk E, Fox KA, Julian D, Lengyel M, Neumann Fj, Ruzyllo W, Thygesen C, Underwood SR, Vahanian A, Verheugt FWA, Wijns W: Management of acute myocardial infarction in patients presenting with STsegment elevation. The Task Force on the Management of Acute Myocardial Infarction of the European Society of Cardiology. Eur Heart J 2003, 24:28-66.

2. An international randomized trial comparing four thrombolytic strategies for acute myocardial infarction. The GUSTO investigators. N EnglJ Med 1993, 329:673-682.

3. Dijkmans PA, Juffermans LJ, Musters RJ, van Wamel A, ten Cate FJ, van Gilst W, Visser CA, de Jong N, Kamp O: Microbubbles and ultrasound: from diagnosis to therapy. Eur J Echocardiogr 2004, 5:245-256.

4. Dijkmans PA: Ultrasound contrast agents: from diagnosis to therapy. In PhD Thesis VU University Medical Center, Amsterdam, the Netherlands; 2007.

5. Pfaffenberger S, Devcic-Kuhar B, Kastl SP, Huber K, Maurer G, Wojta J, Gottsauner-Wolf M: Ultrasound thrombolysis. Thromb Haemost 2005, 94:26-36.
6. van Wamel A, Bouakaz A, Versluis M, de Jong N: Micromanipulation of endothelial cells: ultrasound-microbubble-cell interaction. Ultrasound Med Biol 2004, 30: I255-1258.

7. Juffermans LJ, Dijkmans PA, Musters RJ, Visser CA, Kamp O: Transient permeabilization of cell membranes by ultrasoundexposed microbubbles is related to formation of hydrogen peroxide. Am J Physiol Heart Circ Physiol 2006, 29 I:HI595-HI60I.

8. $\mathrm{Wu}$ J: Temperature rise generated by ultrasound in the presence of contrast agent. Ultrasound Med Biol 1998, 24:267-274.

9. Tachibana K, Tachibana S: Albumin microbubble echo-contrast material as an enhancer for ultrasound accelerated thrombolysis. Circulation 1995, 92: | |48-1 I50.

10. Kondo I, Mizushige K, Ueda T, Masugata H, Ohmori K, Matsuo H: Histological observations and the process of ultrasound contrast agent enhancement of tissue plasminogen activator thrombolysis with ultrasound exposure. Jpn Circ J 1999, 63:478-484.

II. Nishioka T, Luo H, Fishbein MC, Cercek B, Forrester JS, Kim CJ, Berglund $\mathrm{H}$, Siegel RJ: Dissolution of thrombotic arterial occlusion by high intensity, low frequency ultrasound and dodecafluoropentane emulsion: an in vitro and in vivo study. J Am Coll Cardiol 1997, 30:56I-568.

12. Porter TR, LeVeen RF, Fox R, Kricsfeld A, Xie F: Thrombolytic enhancement with perfluorocarbon-exposed sonicated dextrose albumin microbubbles. Am Heart $\int$ 1996, 1 32:964-968.

13. Mizushige K, Kondo I, Ohmori K, Hirao K, Matsuo H: Enhancement of ultrasound-accelerated thrombolysis by echo contrast agents: dependence on microbubble structure. Ultrasound Med Biol 1999, 25: |43|-|437.

14. Birnbaum Y, Luo H, Nagai T, Fishbein MC, Peterson TM, Li S, Kricsfeld D, Porter TR, Siegel RJ: Noninvasive in vivo clot dissolution without a thrombolytic drug: recanalization of thrombosed iliofemoral arteries by transcutaneous ultrasound combined with intravenous infusion of microbubbles. Circulation 1998, 97:130-134

15. Siegel RJ, Atar S, Fishbein MC, Brasch AV, Peterson TM, Nagai T, Pal D, Nishioka T, Chae JS, Birnbaum Y, Zanelli C, Luo H: Noninvasive transcutaneous low frequency ultrasound enhances thrombolysis in peripheral and coronary arteries. Echocardiography 200I, 18:247-257.

16. Culp WC, Porter TR, Lowery J, Xie F, Roberson PK, Marky L: Intracranial clot lysis with intravenous microbubbles and transcranial ultrasound in swine. Stroke 2004, 35:2407-24II.

17. Xie F, Tsutsui JM, Lof J, Unger EC, Johanning J, Culp WC, Matsunaga T, Porter TR: Effectiveness of lipid microbubbles and ultrasound in declotting thrombosis. Ultrasound Med Biol 2005, 31:979-985.

18. Alexandrov AV, Molina CA, Grotta JC, Garami Z, Ford SR, AlvarezSabin J, Montaner J, Saqqur M, Demchuk AM, Moye LA, Hill MD, Wojner AW: Ultrasound-enhanced systemic thrombolysis for acute ischemic stroke. $N$ Engl J Med 2004, 35 I:2 I 70-2 I 78.

19. Molina CA, Ribo M, Rubiera M, Montaner J, Santamarina E, DelgadoMederos R, Arenillas JF, Huertas R, Purroy F, Delgado P, AlvarezSabin J: Microbubble administration accelerates clot lysis during continuous $2-\mathrm{MHz}$ ultrasound monitoring in stroke patients treated with intravenous tissue plasminogen activator. Stroke 2006, 37:425-429.

20. Cohen MG, Tuero E, Bluguermann J, Kevorkian R, Berrocal DH, Carlevaro O, Picabea E, Hudson MP, Siegel RJ, Douthat L, Greenbaum $A B$, Echt $D$, Weaver WD, Grinfeld LR: Transcutaneous ultrasound-facilitated coronary thrombolysis during acute myocardial infarction. Am J Cardiol 2003, 92:454-457.

21. De NVVC Richtlijnen Acute Coronaire Syndromen [http:// www.nvvc.nl/UserFiles/File/Pdf/200I acs.pdf]

22. Lichtveld RA, Hartman JAM, De Vries GMJ, Ten Wolde WLM: Landelijk Protocol Ambulancezorg 2005 Zwolle: Dutch ambulance institute; 2005.

23. EPAR for Luminity [http://www.emea.europa.eu/humandocs/ PDFs/EPAR/luminity/065406en6.pdf]

24. 't Hof AW, Liem A, Suryapranata H, Hoorntje JC, de Boer MJ, Zijlstra $\mathrm{F}$ : Angiographic assessment of myocardial reperfusion in patients treated with primary angioplasty for acute myocardial infarction: myocardial blush grade. Zwolle Myocardial Infarction Study Group. Circulation 1998, 97:2302-2306.

25. Gibson CM, Cannon CP, Daley WL, Dodge JT Jr, Alexander B Jr, Marble SJ, McCabe CH, Raymond L, Fortin T, Poole WK, Braunwald E: 
TIMI frame count: a quantitative method of assessing coronary artery flow. Circulation 1996, 93:879-888.

26. Ross AM, Coyne KS, Reiner JS, Greenhouse SW, Fink C, Frey A, Moreyra E, Traboulsi M, Racine N, Riba AL, Thompson MA, Rohrbeck $S$, Lundergan CF: A randomized trial comparing primary angioplasty with a strategy of short-acting thrombolysis and immediate planned rescue angioplasty in acute myocardial infarction: the PACT trial. PACT investigators. Plasminogen-activator Angioplasty Compatibility Trial. J Am Coll Cardiol 1999, 34: 1954-1962.

Publish with Bio Med Central and every scientist can read your work free of charge

"BioMed Central will be the most significant development for disseminating the results of biomedical research in our lifetime. "

Sir Paul Nurse, Cancer Research UK

Your research papers will be:

- available free of charge to the entire biomedical community

- peer reviewed and published immediately upon acceptance

- cited in PubMed and archived on PubMed Central

- yours - you keep the copyright

Submit your manuscript here:

http://www.biomedcentral.com/info/publishing_adv.asp 